NBER WORKING PAPER SERIES

ALTERNATIVE LIBERALIZATION STRATEGIES

Robert E. Baldwin

Working Paper No. 2045

NATIONAL BUREAU OF ECONOMIC RESEARCH

1050 Massachusetts Avenue

Cambridge, MA 02138

October 1986

The research reported here is part of the NBER's research program in International Studies. Any opinions expressed are those of the author and not those of the National Bureau of Economic Research. 
NBER Working Paper \#2045

October 1986

\section{Alternative Liberalization Strategies}

\section{ABSTRACT \\ This paper examines various strategies that have been} proposed for halting the recent drift toward protectionism and restoring a more liberal trading regime. A number of groups and Individuals propose a multilateral approach aimed at immediately reducing all forms of import barriers and export subsidies on a nondiscriminatory basis across all commodities. Others, who doubt that all major countries are prepared at this time to pursue this approach, favor a bilateral and regional strategy in which those countries willing to liberalize conclude agreements that are left open for others to join. They believe that this approach will eventually lead to multilateral liberalization. Some groups belleve that nelther of these approaches will succeed and that an aggressive stategy of quickly retaliating against the unfair trade practices of other countries is the best way to bring countries to the bargaining table for multilateral negotiations.

The merits and problems of these various strategles are considered as well as their prospects for implementation. The importance of other conditions necesary for trade liberalization such as satisfactory domestic and international macroeconomic conditions are also discussed.

Robert E. Baldwin Department of Economcs University of Wisconsin Madison, WI 53706 


\section{ALTERNATIVE LIBERALIZATION STRATEGIES}

Robert E. Baldwin, University of Wisconsin-Madison

All the major trading blocs have expressed dissatisfaction. with the illiberality of the present international trading system. The United States complains that most other nations have failed to open their markets to the extent it has and that many nations artificially promote exports to the United states by unfair subsidization and dumping. Members of the European Community contend they are unable to penetrate the markets of Japan and many developing countries because of protectionist policies while at the same time Europe is being flooded with exports of manufactured goods from these same countries. In. response, Japan maintains that its competitive ability is based on free market forces and that, with few exceptions, its markets are as open as those of other major industrial nations. The smaller industrial nations also complain about the lack of open. markets in many countries, and the land-abundant members of this grnup join the United states in strongly protesting the protection given agriculture in the European Community and Japan. The developing countries object to the high barriers erected in the industrial nations against such labor-intensive manufactured goods as textiles and to the high effective rates of protection 
on many processed natural resource products.

This dissatisfaction with the existing trading system has led to a number of proposals for halting the protectionist trend of recent years and restoring a more liberal international trading regime. The proposals differ in three major ways: (i) the economic, political, and social factors deemed important in analyzing the prospects of greater liberalization; (ii) the degree of liberalization which their proponents seek; and (iii) the extent to which they address the alleged causes of breakdown of the postwar liberal trading order. It is the purpose of this paper to analyze and evaluate a selected number of these proposals.

The first section of the paper considers two broad analyses of trading regimes that emphasize different factors in understanding the prospects for a return to a more liberal trading order: one stresses the economic power relationships among trading nations and the second stresses the legal framework in which trade and other economic institutions operate. Section two discusses the importance of satisfactory domestic and international macroeconomic conditions and the next three sections focus on alternative trade policy strategies for moving toward a more liberal trading regime. Section three analyzes proposals for utilizing a multilateral approach, and section four sets forth the arguments for proceeding on a bilateral and regional basis toward more open trade. The fifth section considers a trade strategy of aggressive retaliation with 
discriminatory taxes and subsidies to force certain countries to abandon their beggar-thy-neighbor policies and accept a liberal multilateral trading order. The sixth section evaluates the three approaches by considering the likelihood of their being implemented and the extent to which, if adopted, they will serve to move the trading community toward multilateral liberalization. The last section puts forth another alternative, namely, holding a negotiation on subsidies and other unfair trade practices, for halting the spread of protectionism and setting the stage for multilateral liberalization.

I. THE STRUCTURE OF NATIONAL ECONOMIC POWER, LEGAL RESTRAINTS ON TRADE POLICYMAKING, AND THE LIBERAL TRADING ORDER

According to the theory of hegemonic stability associated with such writers as Kindleberger (1973), Gilpin (1975), and Krasner (1976), when a nation emerges as the dominant and most economically efficient world power - as did the United Kingdom in the 19 th century and the United States in the years following World War II - that nation finds it in its economic and political interests to promote the collective good of global stability through a liberal international trading and monetary regime. When the hegemon begins to lose its dominant position, howeveras the United States has since the mid-1960s - the free rides given to smaller states by the hegemon's liberal trade policy, coupled with the most-favored-nation principle that this policy involves, are no longer politically tolerable to domestic 
economic interests. Consequently, the early versions of this theory predicted the inevitable collapse of the liberal postwar trading regime and a return to general protectionism.

When the dire initial predictions of the formulators of the hegemonic explanation of regime change failed to materialize, modifications in the theory appeared. Keohane (1984) argues, for example, that independent states have complementary selfinterests that enable cooperation to take place within a nonhegemonic environment. Moreover, international institutions such as the GATT facilitate such cooperation. In his view, we are now in a period of transition between the hegemonic cooperation of the postwar period and a new state of affairs characterized either by the current discord or by post-hegemonic cooperation. Whether discord or cooperation prevails in trade matters depends, according to Keohane, on how well governments take advantage of existing international institutions to make new agreements on trade matters and to ensure compliance with old ones. He points to the Multifiber Arrangement, however, as evidence that the cooperative approach does not necessarily imply the choice of liberal trade policies.

The late Jan Tumlir also viewed the problem of achieving greater trade liberalization in broad political and legal terms. According to Tumlir (1984), the disintegration of the postwar liberal trading regime is due to legislatures' improper delegation of power to the executive branch of government, coupled with the lack of either international or domestic legal 
control over the executive's international economic policies. Tumlir criticizes the diplomatic authors of the GATT on the grounds they misstated the case for a liberal trade regime by emphasizing that the benefits would stem from the "concessions" of other countries rather than from the efficiency effects of lower import prices and they conceived of the GATT as a universal organization in which the wishes of all members should be satisfied. In Tumlir's view, the constant negotiation required to keep members satisfied has eroded the basic rules of the organization.

While Tumlir was pessimistic about the prospect of returning to a truly liberal international trading order, he observed some offsetting tendencies to the excessive delegation of power to the executive branch, for example, the increasing use by private individuals of the courts to complain of the arbitrary and unreasonable exercise of trade-regulatory powers delegated to national executives. He welcomed the U.S. Supreme Court's decision in the Chadha case which declared the legislative veto to be inconsistent with the constitutional division of powers between the executive and legislative branches of the U.S. government, seeing it as a step that will force Congress to be more careful when it delegates powers to the executive branch.

\section{MACROECONOMIC POLICIES AND LIBERALIZATION}

While policy-oriented economists recognize the importance of the political and legal foundations of an international economic 
regime, most believe that it is possible to make a significant move toward a more liberal international trading order through practicable changes in existing economic institutions and policies. However, many economists, such as Bhagwati (1983), Bergsten (1984), Donges (1984), Hufbauer and Schott (1985), and Aho and Aronson (1985) argue that this effort must involve much more than simply changes in the trade area. Because of the increasing interdependence of the world economy, the prospects for reducing protectionism depend not only on satisfactory international monetary and capital-transfer conditions but on domestic monetary, fiscal and regulatory conditions within the major trading nations.

Current protectionist pressures in the United States highlight the importance of understanding the interrelationships between domestic macroeconomic policies and trade policy. The huge U.S. trade deficit, which reached $\$ 140$ billion in 1985 , has sparked the introduction of some 200 trade bills in the U.S. Congress, most of which their sponsors justify on the grounds that they will help reduce this deficit. The Trade Emergency and Export Promotion Act, introduced by Congressmain Richard Gephardt and Congressman Dan Rostenkowski, who chairs the Ways and Means Committee which is the key House committee dealing with trade legislation, typifies these bills. The purpose of the measure, according to its authors, is to "reverse the enormous shortfall in our balance of trade," which they attribute to "1) the overvalued U.S. dollar, 2) the persistent growth of foreign 
unfair trade barriers, and 3) the lack of a coherent U.S. trade policy" (Rostenkowski and Gephardt, 1985). The bill mandates the imposition of a $25 \%$ duty on any major U.S. trading partner (defined as a country that has over $\$ 7$ billion in annual trade with the United States) whose exports to the United States exceed its imports from the United States by $65 \%$ or its exports to the world exceeded its imports from the world by 50\%, excluding oil trade. The senate version of the bill also requires the U.S. Trade Representative to apply countersubsidies on exports of agricultural products when other countries are subsidizing their agricultural exports.

Unfortunately, the Congressmen's explanation of the causes of the U.S. trade deficit is incomplete and flawed. What is worse, there is no reason to expect that the import-restricting and export-promoting actions mandated in the bill would reduce the U.S. trade deficit. As economists have been pointing out for many years, trade deficits or surpluses are largely determined by macroeconomic conditions. The difference between a country's total exports and imports of goods and services represents its foreign investment which, together with domestic investment, equals its aggregate investment. Aggregate investment is, in turn, by definition equal to aggregate saving, which is composed of private saving plus the difference between government taxes and government expenditures, in other words, government saving. The U.S. trade deficit has its roots in a significant fall in aggregate saving brought about by the increase in federal 
government expenditures relative to tax collections. Since private saving has not increased to offset this decline in government saving, the effect of the increased government expenditures must be to crowd out either domestic investment or net foreign investment. The rise of interest rates as the government has bid for funds to finance its deficit in an environment of tight monetary policy has not only tended to discourage private investment but has led to a return of U.S. funds previously invested abroad and an inflow of foreign capital. Consequently, the trade balance has turned significantly negative and the value of the dollar has risen substantially compared to the late 1970 s as the international demand for dollars has increased. Fortunately, within the last year the dollar has depreciated significantly, a development that is likely to reduce the pressures for protectionism considerably once its trade-balance effects occur.

Unfair trade practices and the lack of a coherent U.S. trade policy have had only a minimal effect on the U.S. trade balance, since they have little effect on aggregate savings or investment. Unfair trade practices can, of course, cause trade-balance deficits in particular product sectors. But under a flexible exchange rate system, these deficits lead to a marginal depreciation of the dollar and thus offsetting marginal increases in exports and decreases in imports in other sectors.

Similarly, the import surcharges required under the Rostenkowski-Gephardt bill are unlikely to have an appreciable 
effect on the U.S. trade balance. The increased profits and thus saving by import-competing industries which benefit from protection will tend to be offset by lower profits and saving in export sectors that are harmed by the protection. Furthermore, most estimates of the revenue implications of proposals for import surcharges conclude that any favorable balance-of-trade effects will be offset by a further appreciation of the dollar. Retaliatory actions by other countries would also make the deficit problem worse.

While the U.S. domestic policies that have brought about the trade deficit have benefited export industries in other countries, the outflow of capital from these countries represents funds that might otherwise have gone for domestic investment purposes. Furthermore, the high level of U.S. interest rates has forced other countries to maintain higher interest rates than they desire in order to control the capital outflow. This has depressed investment in such sectors as construction and thereby further exacerbated their unemployment problem. In Europe and other areas where unemployment is a serious problem, it seems clear that better employment conditions are a political prerequisite to any significant trade liberalization.

A number of economists, besides emphasizing the need for the better international coordination of domestic policies as part of a strategy for significant trade liberalization, also argue that trade-liberalizing efforts must be linked to international monetary reform, aimed at limiting the risk of severe 
misalignment of the exchange rates of the major countries, reducing the volatility of these rates, and at achieving a longrun solution to the debt problem of many developing countries. They welcome the recent successfully coordinated efforts of the major trading nations to bring down the value of the dollar and reduce interest rates, but they advocate more formal ârrangements. Bhagwati (1983) and others also believe that liberalization by the developing countries is unlikely unless larger financial resources are made available to them to ease their short-run debt repayment pressures. Some suggest tying at least part of this increased financial assistance to tradeliberalizing actions by the recipients.

\section{THE MULTILATERAL APPROACH TO TRADE LIBERALIZATION}

Proponents of the multilateral approach to liberalization, including such recent articulators of this position as the GATT "Wisemen's" Group (1985), the scott study Group of the Trade Policy Research Centre (1984), Curzon and Price (1985), Aho and Aronson (1985), Donges (1984), and Preeg (1985), believe that reductions in all forms of import barriers and export subsidies on a nondiscriminatory basis across all commodities will create the most favorable conditions for high, sustained rates of income and employment growth throughout the world economy and for harmonious political relations among nations. They view the increased use of trade-distorting measures in recent years as a regrettable consequence of governments' unwise macroeconomic 
policies and reacting to political pressures from particular economically inefficient industries, and they maintain that only through a politically bold program of significant liberalization in all trading sectors can the present creeping protectionism be reversed. Most advocates of this approach favor certain institutional and policy changes to facilitate the liberalization process and prevent the recurrence of protectionism.

Elimination of the use of voluntary export restraint agreements (VERS) and orderly marketing agreements (OMAs) is high on the agenda of proponents of multilateral liberalization. These measures to protect domestic industries from injurious import competition are condemned because they curtail trade on a selective country basis and they involve the use of quantitative restrictions. Advocates of multilateral liberalism would require all safeguard actions to be brought within the most-favorednation framework of the GATT. Most also argue that the protection granted under such actions should only be in the form of tariffs, and any tariff increases should be temporary and degressive.

There is, however, a general recognition that some modifications in safeguard procedures are needed to moderate the pressure to resort to selective protection. There is widespread agreement on no longer requiring the country that increases protection under GATT safeguard provisions to compensate other countries with cuts in duties on other products, provided the protection is temporary and degressive. Retaliation would also 
be ruled out in these circumstances.

More effective measures to facilitate the adjustment of workers and capital owners in import-injured industries are also advocated to ease the pressures for selective protection. At present, only the United States and Canada have special assistance programs specifically aimed at import-injured industries, and recently a number of writers, such as Hufbauer and Rosen (1986), Mutti (1985), Schultz and Schumacher (1984), and Lawrence and Litan (1986), have put forth proposals for making these more effective. A novel feature of some of these proposals is that the adjustment assistance to workers would be financed by converting existing quotas to tariffs or by auctioning off the quotas. To overcome the criticism that additional unemployment payments encourage displaced workers to remain unemployed for longer periods, Mutti (1985) and Lawrence and Litan (1986) propose that, in addition to extended unemployment insurance payments and job retraining programs, workers be given the incentive to take new jobs by partially compensating them if their earnings are lower in their new employment. The Reagan Administration proposed in 1984 that displaced workers be given wage vouchers that would enable employers who hired them to claim a direct cash subsidy for a specified percentage of the wages paid the workers. While more evidence is needed to reach a firm conclusion on the effectiveness of this approach, one American experiment with wage vouchers proved very disappointing (see Burtless, 1985). In 
acldition to special assistance to workers displaced by import competition, most proposals also include provisions, such as relaxed merger standards, to encourage the restructuring of the injured industry to enable it to become more efficient.

Supporters of multilateral liberalization regard the highly protected textile and apparel sector as a prime candidate for structural adjustment. They would use the occasion of the expiration of the Multifiber Arrangement III in 1986 to set in place the procedures for bringing this industry back within normal GATT rules. World steel trade, which is becoming increasingly subject to discriminatory quantitative restrictions, would be liberalized. Agriculture also stands out as a sector where both domestic and international measures distort world trade to a significant degree, and advocates of general liberalization would progessively enlarge the scope for the interplay of market forces in trade in agriculture. An initial step would be to extend the GATT ban on export subsidies to agricultural products.

Those who advocate a return to stricter enforcement of the unconditional most-favored-nation principle have some disagreement on the Generalized System of Preferences (GSP). The GATT Wisemen's Group and the scott Group believe that these tariff preferences have been of limited value to developing countries and, indeed, have acted to divert the efforts of these countries from reciprocal negotiations that would have yielded them greater benefits. Others, such as Preeg, are willing to 
"graduate" the more advanced developing nations from tariff preference and other forms of special and differential treatment but are reluctant to eliminate such treatment entirely.

There seems little doubt that a return to multilateral liberalization cannot be effective without greater international consensus on the appropriate use of domestic subsidies. Most U.S. officials and business leaders believe, for example, that many countries are unfairly subsidizing their industrial production, thereby causing disruptive import surges in U.S. markets. In response, these countries claim they are using domestic aids for legitimate development or adjustment purposes.

The new Subsidies Code negotiated in the Tokyo Round is considered by many to be too general to be of much use in settling disputes that arise on this issue. Complaining about the subsidizing actions of other countries, the U.S. points to the part of the Code in which signatories agree to seek to avoid the use of subsidies that "may cause or threaten to cause injury to a domestic industry of another signatory or seriously prejudice the interests of another signatory or may nullify or impair benefits accruing to another signatory under the General Agreement." Other nations, in support of the use of subsidies, point to the following statement in the code: "signatories recognize that subsidies other than export subsidies are widely used as important instruments for the promotion of social and economic policy objectives and do not intend to restrict the right of signatories to use such subsidies to achieve these and 
other important policy objectives which they consider desirable." As the GATT Wisemen's Group pointed out, there is a pressing need for revision and clarification of the GATT rules on subsidies.

Besides calling for a strengthening of the subsidies code and other codes negotiated in the Tokyo Round, proponents of a revitalized multilateral approach to liberalization press for various institutional reforms in the GATT. Improved dispute settlement procedures stand high on their list of needed reforms. To replace the current practice of giving preference to government officials as members of dispute settlement panels, it has been proposed that members be drawn from a small list of nongovernmental experts who over time would be able to develop a harmonious body of case law covering various types of disputes. It has also been proposed that the countries involved in a dispute no longer have the right to veto the acceptance of a panel report by the members as a whole. In addition, speedier and more detailed reporting procedures have often been called for as a means of increasing confidence in this method of settling trade disputes.

Granting greater authority to the Director-General is frequently proposed for a better-functioning GATT. For example, the GATT Secretariat might be given the authority to collect information on the extent of protection, monitor trade policies for possible violations of GATT rules, and enter the negotiations over disputes at an early stage.

In addition to strengthening existing GATT rules, those 
pressing for a return to a more liberal multilateral approach generally favor broadening the scope of trade covered by GATT rules. Services trade is the most frequently mentioned area for the extension of GATT rules, but trade in intellectual property and high technology items and trade-related investment issues are other fields proposed for greater coverage by GATT. The objective would be to reduce the use of many trade-distorting practices that have arisen in these areas and thereby widen the support for liberalization. Negotiating new codes of good conduct, as was done in the Tokyo Round for subsidies and government procurement policies, is the most frequently suggested technique for dealing with these subjects.

\section{THE BILATERAL AND REGIONAL APPROACH TO LIBERALIZATION}

Some observers of the trade policy scene, such as Hufbauer (1984) and Hufbauer and schott (1985), believe that the multilateral approach would have little impact on the deeply embedded distortions existing in the present world trading system. In their view, bilateral and plurilateral initiatives should be welcomed on the grounds that they will eventually mature into multilateral liberalization. Aho and Aronson (1985) and others favor efforts to liberalize on a multilateral basis but are prepared to fall back to a bilateral and regional approach if multilateralism fails.

All recognize that there has been a significant increase in bilateralism and regionalism over the last forty years. The most 
important regional trading organization is, of course, the European Community (EC). Starting out with six member countries in 1957, it now includes, with the recent admission to membership of Portugal and Spain, twelve countries. Moreover, the Community has negotiated special free trade arrangements with members of the European Free Trade Area (EFTA) and with the former African, Caribbean, and Pacific colonies of Community members. Various free trade groupings of developing countries, such as the Association of Southeast Asian Nations (ASEAN) and the Latin American Free Trade Area (LAFTA), have also been formed. Recently the United States has also moved in this direction with the Caribbean Basin Initiative, the free trade arrangement with Israel, and the launching of negotiations aimed at a free trade agreement with Canada, as have Australia and New Zealand with their Closer Economic Relations Agreement. The extension of tariff preferences to the developing countries by the industrial countries and the negotiation of nontariff trade barrier (NTB) codes during the Tokyo Round that apply only to those members that sign them are other illustrations of the abandonment of the multilateral approach in dealing with trade issues.

Advocates of the bilateral and regional approach, either as a first-best or second-best means of achieving liberalization, would build upon previous uses of this technique. For example, given the strong opposition of some countries to the inclusion of such issues as services trade and trade-related investment requirements on the agenda of the next GATT round, they suggest 
seeking selective agreements such as the Tokyo Round NTB codes or, if this path is blocked, negotiating bilaterally on these matters, using the threat of selective retaliation under national laws to bring about such negotiations. Agreements reached would be open-ended in the sense that any country would gain the trade benefits of the liberalization which reduced its own barriers. The hope is that, as these benefits increase with increasing membership in an agreement, those reluctant to participate would find it in their interest to join so that the liberalization eventually is multilateralized. Even if this does not come about, the proponents of the regional approach maintain that it would produce greater liberalization than would efforts to pursue multilateral liberalization directly.

\section{THE AGGRESSIVE APPROACH TO LIBERALIZATION}

Critics of the bilateral and regional approach to liberalization fear that it encourages further breakdowns in the multilateral system and the politicization of world trade. Citing, for example, the resistance of the developing countries to multilateral tariff reductions that gradually erode the diversionary value of their tariff preferences, they point out that vested interests quickly emerge to protect the economic inefficiencies implicit in bilateral and regional arrangements, making it difficult to turn such agreements into liberal multilateral arrangements. They further argue that some of the countries taking advantage of the present lack of reciprocity in 
the trading system will choose to remain outside of bilateral and regional agreements that require them to open their markets to a greater extent.

An aggressive approach to liberalization is therefore proposed, and Democratic and Republican leaders in the U.S. Congress are its most vocal proponents, as Ahearn and Reifman (1986) point out. The Rostenkowski-Gephardt bill outlined in Section II illustrates this aggressive approach. Congressional leaders and, in fact, most members of Congress, believe that the only way to restore open markets is, first, to threaten retaliation against countries that do not provide access to their markets that is substantially equivalent to that offered by the United states, and then to carry through with the retaliation if they do not respond in an appropriate manner. The retaliation would take the form of discriminatory increases in U.S. protection.

The existence of a substantial trade deficit with another country or the failure of exports and imports to grow at approximately the same rate from a particular base period is regarded as sufficient evidence that the other country is not providing equivalent market access. As Cline (1983) points out, this new notion of reciprocity is unilateral in nature and means scrapping trade commitments agreed on in previous negotiations.

Another important element in the aggressive approach to liberalization is vigorous retaliation against unfair trade practices. For example, although GATT rules do not presently 
regard subsidizing agricultural exports as unfair, most members of Congress favor matching the EC's subsidies of agricultural exports with subsidies for U.S. agricultural products. Various forms of assistance to domestic sectors such as subsidies to high tech industries or financial aid to depressed firms would be met either by equivalent subsidies to U.S. manufacturers of the same goods or by discriminatory protection that denies U.S. markets for the products of these sectors.

The premise behind the aggressive approach to liberalization is that making it impossible for countries to increase their export markets by engaging in unfair trade practices will eventually eliminate such "beggar-thy-neighbor" activities, since the instigators will have nothing to gain by these actions. At that point, each country will come to see that only through a policy of open and reciprocal trade is it possible to obtain the income and employment benefits of trade. Defenders of the aggressive approach maintain that the enforcement of current GATT rules is now so lax and the rules so vague that it pays some countries to try to avoid granting full reciprocity and to undertake unfair trade practices.

\section{AN EVALUATION OF ALTERNATIVE APPROACHES TO LIBERALIZATION}

The majority of economists in the industrialized nations and many economists in the developing countries strongly favor significant trade liberalization on a multilateral basis. In their view, historical experience and economic analysis clearly 
indicate that multilateral liberalization promotes world economic prosperity and growth whereas restrictionism is associated with sluggish economic performance and periodic balance-of-payments crises. How then do we explain the existence of so much protectionism and discrimination?

Economists frequently attribute it to the lack of political will on the part of governments. The implication is that while governments may know that liberal trade policies are best for promoting long-run economic welfare, they lack the resolve to forego the political support of narrow special interest groups who may lose in the short run from liberalization. Although there is merit in this explanation, the matter appears to be considerably more complex than "lack of political will" suggests. This explanation is also usually put forth with a finality that discourages further research into the process of political decision making and it may delude economists into believing the solution to thwarting protectionism is easier than is in fact the case. On the basis of the political-will hypothesis, one tends to conclude that greater efforts to educate public officials and the public generally on the advantages of liberal trade policies are the best way to restore multilateral liberalism. However, empirical work in the area of the political economy of trade policy, such as that of cheh (1974), Caves (1976), Lavergne (1983), Baldwin (1985), and Anderson and Baldwin (1986), supports the view that public officials support protectionism not only because of political pressures from special groups but also out 
of concern for equity and the adjustment problems workers face as a result of industry-injuring shocks, perceived unfair trade practices by other countries, and the need to maintain a strong domestic industrial base. Consequently, to better understand how liberal trade policies can be implemented, economists must analyze the economic and political forces that shape the pressures for protectionism.

The protectionism currently threatening the international trading regime has its roots in the significant structural changes in world production that have brought about a decline in the dominant economic position of the United states, a concomitant rise of the European Community and Japan to international economic prominence, and the emergence of a highly competitive group of newly industrializing countries. After World War II the trading regime expected to develop involved a sharing of responsibility by the major economic powers for maintaining open and stable trading conditions. However, the unexpected magnitude of the immediate postwar economic and political problems thrust the United States into a hegemonic role. U.S. economic dominance manifested itself in the trade, finance, and energy fields, and enabled American producers to establish predominant export and investment positions abroad. Then by facilitating the reconstruction and development of Western Europe and Japan and the industrialization of some of the developing countries, U.S. hegemonic activities led eventually to a marked decline in the American share of world exports and a 
significant rise of import competition in both labor-intensive sectors and certain oligopolistically organized industries. These developments also significantly diminished the leadership authority of the United States.

Most governments in Western Europe responded to the shifts in comparative advantage by providing injured manufacturing industries with subsidies and injured agricultural sectors with greater import protection and export subsidies. Such behavior was consistent with the active role played by the governments of these countries in promoting reconstruction and development.

For the United States, where intervention to assist injured industries was not accepted government policy, the adjustment process has been difficult. When the pressures for adjustment First became noticeable in the late 1950 s and early 1960s, it was thought they could be handled by pressing for greater liberalization to reduce the trade-diversionary impact of the formation of the European Community and also to open markets in Japan and the developing countries. After this proved, however, to provide no more than temporary relief from the need for major restructuring, and especially after U.S. macroeconomic policies led to a substantial appreciation of the dollar, government, business, labor, and agricultural leaders began to adopt the nowprevalent view that unfair trade practices are a major cause of U.S. competitive problems. By urging more vigorous enforcement of U.S. statutes and GATT rules on unfair trade, they are able to press for import protection and still claim support for the open 
trading regime the United states did much to establish after World War II. It is clear, however, that the U.S. government is not now prepared to begin the process of dismantling protection in such key sectors as textiles and apparel or in steel. There is pressure for reform in agriculture but this is an export sector for the United states. It is not even evident what the U.S. position on selectivity will be.

Nor can much in the way of real pressure for multilateral Iiberalization be expected from the Community. Most members face severe structural adjustment and unemployment problems, and a strong ideological commitment to free market policies is lacking in all but a few countries. This means that chances are very slim that the Community will agree to significant changes in the GATT rules on agriculture. Reductions in Community subsidies for depressed industries and for the development of high tech sectors also appear unlikely in the foreseeable future.

The way the Community is organized works against the development of any major initiative on liberalization. Although its members negotiate as a group through the European Economic Commission, the real power remains in the hands of the individual states, any one of which can block major change in trade policy. Given the highly divergent political, social, and economic conditions of the member countries, particularly with the addition of Greece and now Portugal and spain, it is almost impossible for the Community to take the lead in restoring multilateral liberalism or, indeed, to support this initiative. 
Japan is likely to support significant liberalization but not to initiate a move in this direction. Like the United states in the 1920s, it is performing as a major trading power on the export side but not on the import side. Conventional barriers appear reasonably low, but the existence of large companies that cover a wide variety of industries and the tradition of consumer loyalty to these companies make it difficult to break into the Japanese industrial market. Attitudes of "Buy Japanese" that stem from efforts of this natural resource-poor country to become a major industrial power, an apparent aversion to unfamiliar products, especially foreign goods, and language and cultural differences further contribute to the difficulty in penetrating Japan's markets for manufactured goods. Thus, it is not clear that traditional liberalization measures will, in fact, do much to open Japanese markets.

The developing countries are still unwilling to undertake significant liberalization themselves. They are likely to continue to push for further "special and differential treatment" from the developed countries rather than for major liberalization actions by them. The strong opposition of the developing nations to efforts to liberalize trade in services or reduce traderelated investment requirements will also limit the scope of any agreements on these issues in the next GATT negotiating round.

These positions of the major trading blocs make it unlikely that we will see significant liberalization in the foreseeable future. To expect that, under present international economic 
relationships, countries will somehow find the "political will" to undertake this action seems to be wishful thinking. Another round of GATT trade negotiations is likely to begin shortly, but other than extending GATT rules to services trade, counterfeiting, and intellectual property and introducing some changes in the dispute settlement procedures, the main benefit from the negotiations may be simply to hold back further protectionism.

At the same time GATT-sponsored multilateral negotiations are proceeding, there are likely to be additional bilateral and regional agreements negotiated. The greater use of bilateral negotiation to settle disputes seems to be a positive step in maintaining an open and fair trading system. The GATT disputesettlement procedures have proved too cumbersome for dealing with the dozens of disputes on nontariff issues that exist at any one time and mainly concern only a few countries. Some countries seem to take advantage of this fact by engaging in clearly unfair trade practices in the hope that the injured countries will be discouraged from utilizing GATT dispute-settlement procedures because of their time-consuming and costly nature. Responding on a bilateral level to such actions and threatening retaliation unless the dispute is settled quickly has proved a useful way to deal with this problem.

In contrast, the efficacy of bilateral and regional agreements as a means of promoting greater liberaiization is more problematical. In my view, these are not to be welcomed as a step toward multilateral liberalization. The motivation for 
bilateral or regional agreements is usually not to achieve mutual economic gains through liberalization but to strengthen political ties through greater trade. It is a way for nations to band together to achieve greater collective political and economic power. There seems to be a strong desire to expand the size of regional groupings in order to display greater political and economic strength vis-à-vis other large economic powers, but there is resistance to merging the major groupings to achieve multilateral liberalization because this would undermine the political identities that are the reason for the creation of the trading blocs. Thus, in the end these agreements may act as a barrier to multilateral liberalization.

Pursuit of the aggressive trade policy approach also involves considerable risk for achieving an open trading system. This is most apparent in attempts of the large trading blocs to effect change in each others' behavior by threatened retaliation. To make a threat of retaliation credible, it is usually necessary to publicize the alleged unfairness of the other's actions. In turn, the other trading power tends to publicize the threatened action and its unfairness to deter the retaliation. Typically, the news media tend to give wide and sympathetic circulation to their own country's national viewpoint and the dispute quickly becomes a matter of national pride. It then is politically very difficult for the government of a major trading power to accept retaliation and discontinue the practices that provoked it. Counter-retaliation is the most likely response. While a 
retaliatory war may not necessarily result, the outcome is almost surely not greater liberalization; an equilibrium with greater distortion of world trade is more likely.

The retaliatory approach may be effective for a large trading power when it is used against a small country. A small country is generally unable to cause economic injury by retaliating against a large trading nation, but can be badly hurt itself by aggressive actions by the large power. The difficulty with such aggressive action is that, while it may force a small country to stop certain practices, it is at the cost of worsening political relations with the small countries that see it as exploitation. Large countries are often reluctant to pay this political price since they rely on the support of small countries in their power struggle against other large powers.

\section{A NEGOTIATION ON SUBSIDIES AND OTHER UNFAIR TRADE PRACTICES}

The preceding evaluation of the main proposals for achieving multilateral liberalization leads one to conclude that the most likely scenario for the rest of the 1980 s is a continued drift toward further distortions of world trade and greater use of discriminatory measures. The main reason for this pessimism is that the United states -- the traditional leader of the push for multilateral trade liberalization -- is in danger of abandoning this role and concentrating on bilateral and plurilateral agreements coupled with an aggressive trade policy stance toward outsiders. Given the unlikelihood that the European Community, 
Japan, or the developing countries will provide any real leadership for multilateral liberalization, the trading world will most likely be divided into large trading blocs supported by special (often distortionary) relationships and with trade between these blocs being regulated to a considerable degree.

As I have suggested elsewhere (Baldwin, 1985), another strategy that might prevent this outcome is to channel the dissatisfaction of the United states and other countries with the present regime into a multilateral negotiation that deals directly with the sources of this dissatisfaction. This would involve a comprehensive negotiation covering subsidies and other unfair practices, such as those dealing with technical barriers to trade and government procurement policies, that would be conducted in a manner similar to the item-by-item technique formerly used in tariff negotiations and in the determination of items to be covered by the government procurement code. In the crucial area of subsidies, the objective would be to phase out particular subsidies gradually, bind their level for specified periods of time, or perhaps introduce export taxes (where permitted) to offset the export-subsidizing element in domestic subsidies. The incentives for a country to engage in such negotiations would be 1 ) the prospect of reductions in others' subsidies in return for its willingness to reduce its own subsidies, and 2 ) the threat that others will carry out the countervailing duty actions permitted by GATT rules.

Each country would undertake a comprehensive evaluation of 
all the subsidizing and other unfair practices of other countries that it believes are causing material injury to any of its industries, seriously prejudicing its interests, or nullifying or impairing its GATT benefits. Each participant would then make specific requests of other countries on the reduction or offset of these practices. At the same time, each would announce the countervailing duty and other actions it was prepared to initiate if bilateral or multilateral negotiations were not successful. If past experience is any guide, most countries would be wiling to enter into serious negotiations given the possibility that many other countries nay impose countervailing duties or other restrictive actions against their exports.

The negotiations would begin with the "confrontation and justification" procedure used in the Kennedy Round for claiming exceptions to the 50 percent linear-cut rule. Countries that thought, for example, that a particular subsidy by another participant was inconsistent with GATT rules would present their evidence in a GATT meeting. The subsidizing country would be asked to explain the purpose of the subsidy, any government plans to phase it out or modify it, and why it believed the subsidy was consistent with the rules. After any changes in request lists or plans for retaliation resulting from the confrontation and justification procedure, the negotiating process would begin with an exchange of offer lists specifying what, if anything, countries were willing to do to phase out particular subsidies, bind other subsidies, impose export taxes to offset their injury- 
causing effects, or take other appropriate action to respond to the concerns of other participants. At this stage either a "confronter" or "justifier" on a particular subsidy could also call for the formation of a GATT panel of experts to render a non-binding decision on whether the subsidy was consistent with GATT rules.

The negotiation would then proceed on both a multilateral and bilateral basis with any participant having the right to request a meeting with other participants to discuss a particular subsidy or other allegedly unfair trade practice. In some instances, several countries would meet with a particular country to seek its agreement to phase out, reduce, or otherwise modify an allegedly unfair practice to meet the concerns of the others. In other circumstances, bilateral meetings may be more appropriate, even if the impact of the practice extends to more than one country. The GATT Secretariat would play an active role in coordinating the negotiation and ensuring that all promising lines of agreement were explored.

After these negotiations, each country would decide the extent to which it was prepared to (1) modify its subsidizing and other allegedly unfair practices and (2) proceed with countervailing duty and other retaliatory actions against other countries and particular practices. For example, even if two countries believed their subsidies on certain products were consistent with GATT rules, they may each be willing to phase out their subsidy in return for the phasing out of the subsidy by the 
wher country. For the Inited states, any such agreements reached would be submitted by the President to the Congress for approval and would include the necessary domestic implementing legislation. Industries covered by the agreements would be precluded from seeking countervailing duties during the time period covered by the agreements, just as industries covered by the reciprocal tariff agreements negotiated in the 1930 s were not subject to the provisions of the 1930 Tariff Act that required the President to set tariffs that equalized the cost of production of U.S. and foreign producers. The escape clause provisions of Article XIX would still apply, however. When countervailing duties are imposed, they would be presented as technical adjustments consistent with GATT rules rather than as political actions involving matters of national pride.

A greater consensus on the proper role of subsidies may emerge from the negotiating process that would lead to modifications in the subsidies Code. In particular, there seems to be a need to better distinguish between domestic subsidies of the beggar-thy-neighbor type and those that contribute to the efficient growth of the world economy or can be justified for export-oriented industries on the same adjustment grounds as protection introduced for import-competing industries under Article XIX. Temporary and degressive subsidies should be considered for export-oriented industries that are seriously injured by export competition in third markets. A more difficult problem is distinguishing between subsidies justifiable from an 
economic viewpoint on infant-industry grounds and those aimed simply at shifting market shares at the expense of collective income in the trading community. Most trade officials would require that any permissible subsidies in this group be temporary, degressive, and carefully monitored by the GATT Subsidies Committee. The negotiations may also lead to improvements in the standards and Government Procurement codes and to agreement on a new Safeguards Code strengthening Article XIX.

In conclusion, there are several reasons for considering a GATT-sponsored negotiation on subsidies and other unfair trade practices. Most important, such a negotiation could channel the present dissatisfaction of most countries with the existing trading regime in a constructive direction that leads to multilateral efforts to reform the system and away from the destructive, go-it-alone direction in which many countries seem to be headed. The United States would at last get the opportunity to deal directly and comprehensively with the fundamental issue that is of most concern to many officials. Executive branch officials are continually bombarded with complaints from members of Congress and the business and labor communities about the unfair trade practices of other countries bit, in many instances, have a difficult time coming up with specifics that permit actions under GATT rules. They would be able to deal with these pressures in a systematic fashion in such a negotiation.

Japan and the European Community, who believe that most of 
the complaints by other countries are unfounded, would be able to confront the complainants before the international trading community and force them to come up with substantive objections instead of vague rhetoric. The power of the other members of the GATT to force both the U.S. and the EC to modify what these other countries regarded as unacceptably selfish positions was clearly demonstrated in the Tokyo Round negotiations on the tariffreducing rule. The developing countries and the smaller industrial countries should welcome such a negotiation since it will give them an opportunity to band together as a group to try to modify certain market-contracting subsidizing practices of the large trading powers. The increasing use of bilateral negotiations by the large trading blocs has put the developing countries in a very weak negotiating position. As a group, they will be better able to defend their own subsidizing practices.

There are, however, significant risks in undertaking a negotiation on subsidies and other unfair trade practices. Failure to reach agreements that meet the main concerns of the participants on the fairness issue could touch of $a$ series of countervailing and retaliatory actions that produce a trading regime less satisfactory to all than the present one. The possibility of this outcome should be weighed not only against the chances for a successful negotiation but against the prospects for the trading system if no such action is taken. 


\section{REFERENCES}

Ahearn, Raymond J., and Alfred Reifman (1986), "U.S. Trade Policy: Congress Sends a Message," in R. E. Baldwin and J. D. Richardson (eds.), Current U.S. Trade Policy: Analysis, Agenda, and Administration (Cambridge, MA: National Bureau of Economic Research.)

Aho, C. Michael, and Jonathan D. Aronson (1985), Trade Talks: America Better Listen! (New York: Council on Foreign Relations).

Anderson, Kym, and Robert E. Baldwin (forthcoming), "The Political Market for Protection in Industrial Countries," in Ali M. El-Agraa (ed.), Conflict, Cooperation, Economic Development, and Integration: Essays in Honour of Professor Hiroshi Kitamura (London: Macmilian Press).

Baldwin, Robert E. (1985), The Political Economy of U.S. Import Policy (Cambridge, MA: The MIT Press).

Bergsten, C. Fred (1984), "An Agenda For The London Summit," Statement Before The Joint Economic Committee of the United States Congress, May 14, 1984.

Bhagwati, Jagdish N. (1983), "Rethinking Global Negotiations" in Rethinking Global Negotiations, International Economics Research Center, Current Policy Papers, No.1 (New York: Columbia University, Center for the Social Sciences).

Burtless, Gary (1985), "Are Targeted Wage Subsidies Harmful? Evidence from a Voucher Experiment," Industrial and Labor Review, 39, No.1 (October), 105-114.

Caves, Richard E. (1976), "Economic Models of Political Choice: Canada's Tariff Structure," Canadian Journal of Economics, 9, No. $2,278-300$.

Cheh, J. H. (1974), "United States Concessions in the Kennedy Round and Short-Run Adjustment Costs," Journal of International Economics, 4:323-340.

Cline, William R. (1983), "-Reciprocity': A New Approach to World Trade Policy?" in William R. Cline (ed.), Trade Policy in the 1980s (Washington, D.C.: Institute for International Economics.)

Curzon, Gerard, and Victoria Price (1984), "Is Protection Inevitable?", ordo, Band 35, 121-136.

Donges, Juergen B. (1984), "The International Trading order at the Crossroads," Working Paper No. 199, Kiel Institute of World Economics. 
Gilpin, Robert (1975), U.S. Power and the Multinational Corporation: The Political of Foreign Direct Investment (New York: Basic Books).

Hufbauer, Gary C. (1984), "The Unconditional Most-Favored-Nation Principle: Should It Be Revived, Retired or Recast?", Monash University, Department of Economics and Centre of Policy Studies, Paper Presented at Conference on International Trade Problems and Policies, Melbourne, Australia, February 13-14, 1984.

Hufbauer, Gary C., and Jeffrey J. Schott (1985), Trading for Growth: The Next Round of Trade Negotiations, Policy Analyses in International Economics, No. 11 (Washington, D.C.: Institute for International Economics).

Hufbauer, Gary C., and Howard Rosen (1986), Trade Policy for Troubled Industries, Policy Analyses in International Economics, No. 15 (Washington, D.C.: Institute for International Economics).

Keohane, Robert 0 . (1984), After Hegemony: Cooperation and Discord in the world Political Economy (Princeton: Princeton University Press).

Kindleberger, Charles P. (1973), The World in Depression, 19291939 (Berkeley: University of California Press).

Krasner, Stephen (1976), "State Power and the structure of International Trade," World Politics, 28, April.

Lavergne, R. P. (1983), The Political Economy of U.S. Tariffs: An Empirical Analysis (New York: Academic Press).

Lawrence, Robert E., and Robert E. Litan (1986), Pragmatic Approaches for Preserving Trade (Washington, D.C.: The Brookings Institution).

Leutwiler, Fritz, et al. (1985), Trade Policies for a Better Future: Proposals for Action (Geneva: General Agreement on Tariffs and Trade).

Mutti, John (1985), U.S. Adjustment Policies in Trade-Impacted Industries (Washington, D.C.: National Planning Association).

Preeg, Ernest H. (1985), "Overview: An Agenda for U.S. Trade Policy Toward Developing Countries" in Ernest Preeg (ed.), Hard Bargaining Ahead: U.S. Trade Policy and Developing Countries (Washington, D.C.: Overseas Development Council).

Rostenkowski, Dan, and Richard A. Gephardt (1985), "Introduction of Trade Emergency and Export Expansion Act," Letter to Colleagues, July 14.

Schultz, Siegfried, and Dieter Schumacher (1984), "The ReLiberalization of World Trade," Journal of World Trade, 18 , 
No.3, June/July.

Scott, Brian (1984), Has the Cavalry Arrived?, Special Report, No. 6 (London: Trade Policy Research Centre).

Tumlir, Jan (1984), "International Trade Regimes and Private Property Rights," mimeographed. 